\title{
The Inhibitory Effects by Combined Doses of DDS and several Immunostimulants on the Growth of Leprosy Bacilli Inoculated into Footpads of Hybrid Nude Mice, Jcl:AF-nu
}

\author{
Masaichi GIDOH and Sadae TSUTSUMI \\ (National Institute for Leprosy Research) \\ (Received for publication: September 1, 1989)
}

Key words: hybrid nude mice, immunostimulation, lipoidal amines, muramyl dipeptide, muroctasin

The rapid eradication of leprosy bacilli (LB) with a combination of chemotherapy (CT) and immunostimulation (IS) is an urgent problem in the treatment of leprosy. For examining this synergic effect, a favorable animal model is indispensable whose $\mathrm{T}$ cell immunity is enough to be augmentative by IS whereas LB can enough proliferate. Another indispensability is the use of a bacteriostatic drug which can firstly become bactericidal when combined with IS.

A strain of nude mice, Jcl:AF-nu established by the hybridization of male FNS $/ \mathrm{N}$ ( $n u /$ nu) mice with female IAI $(+\angle+)$ mice in Japan Clea Co. was known to be resistible against infections more than athymic BALB/c mice. On the other hand, the mechanism of action of DDS was well-known to be bacteriostatic.

We examined the inhibitory effects by the combinations of DDS and few immunostimulants on the growth of LB inoculated into foot-pads (fps) of female Jcl:AF-nu mice.

\section{Materials and Methods}

Examined agents: DDS, an immunopotentiative $\beta$-1,3-glucan, ATSO and a water-soluble arthrogenous lipoidal amine, 4-aminomethyl-(2,3-(di-n-decyloxy)-n-propyl)-4-phenylpiperidine hydrochloride (CP-46665) were kindly supplied by Daiichi pharm. Co., One Pharm. Ind. Co. and Dr. K. E. Jensen of Central Research, Pfizer Inc., U.S.A., respectively. N-acetyl-muramyl-Lalanyl-D-isoglutamine (MDP) was purchased from Sigma Chemical $C_{0}$. and its synthetic derivative, $\mathrm{N}^{2}$-MDP-N ${ }^{6}$-stearoyl-L-lysine (MDP-Lys (L18), muroctasin) was kindly supplied by Daiichi Pharm. Co.

Dosing of agents: DDS and ATSO were given by mixing with a heat-stable pellet form chow, MB-6E (Funabashi Nojyo Co.) in the content ratios of 0.01 or $0.002 \%$ and $0.04 \%$, respectively. When both DDS and ATSO were dosed, equal quantity of DDS-and ATSO-chows were well mixed. CP-46665 and MDP were dissolved in physiological saline (PS) and filtered through Millex-GS (pore size $0.22 \mu \mathrm{m}$, Japan Millipore Ltd.). They were intraperitoneally injected to each mouse once weekly in doses of $12 \mu \mathrm{g} / 0.2 \mathrm{ml}$ and 100 or $75 \mu \mathrm{g} / 0.2$ or $0.15 \mathrm{ml}$, respectively. Muroctasin aseptically measured into a sterilized glass homogenizer was irradiated for $1 \mathrm{hr}$ by an UV-lamp (National GL-15) at about $30 \mathrm{~cm}$ from the lamp. It was homogenized with PS containing a very small amount of tween 80 . The homogenate was further diluted to $500 \mu \mathrm{g}$ $\mathrm{ml}$ with PS. A portion $(75 \mu \mathrm{g} / 0.15 \mathrm{ml})$ was intraperitoneally injected to each mouse once per 
week .

Experimental animals: Female Jcl:AF $(n u / n u)$ mice aging 4 or 5 weeks were purchased from Japan Clea Co. All of them were fed with MB-6E chow in inside of vinyl isolators (Sanki Kagaku Kogyo Co.). The sterilized water was freely given.

LB inoculated: Strain of LB was Thai-53 received from Dr. K. Kohsaka of this Institute, which had been passaged 5 or 6 times through fps of athymic BALB/c female mice. The 6 th passage was used in experiment 1 and the 7 th in experiment 2.

Counting of acid-fast bacilli (AFB): Four or six fps of 2 or 3 animals were well minced, triturated and kneaded with 4-or 6-ml PS, respectively. After centrifuged at $330 \mathrm{xg}$ for $3 \mathrm{~min}, 10$ $\mu 1$ of the supernatant or its diluted bacterial suspensions were dried with $10 \mu \mathrm{l}$ each of formol-milk and fixed by exposing to formalin gas for $3 \mathrm{~min}$ followed by heating on vapour for $2 \mathrm{~min}$. The staining method was: in $1 \%$ carbol fuchsin solution for $28 \mathrm{~min}$; in $1 \% \mathrm{HCl} / 70 \% \mathrm{EtOH}$ for $8-9 \mathrm{sec}$; in a Löffler solution (methylene blue solution $(30 \mathrm{ml}$ ) diluted with $100 \mathrm{ml}$ of $0.01 \% \mathrm{KOH}$ ) for 28 $\mathrm{sec}$, at room temperature.

Volumetry of fp swelling: The instrument used was a digital volumeter, MK-550 (muromachi Kikai Co.). The volume of liquid in its cell was adjusted by a sterilized water containing a small amount of tween 80 . The volumetry was performed in inside of a clean bench, Hitachi PCW-13038 SG3. In experiment 1 , it was once examined just before the last sacrifice of animals. In experiment 2 , it was 3 times examined immediately after sacrifice of animals by their neck bone puncture.

\section{Results}

The chemical structures of examined immunostimulants are shown in Figure 1.
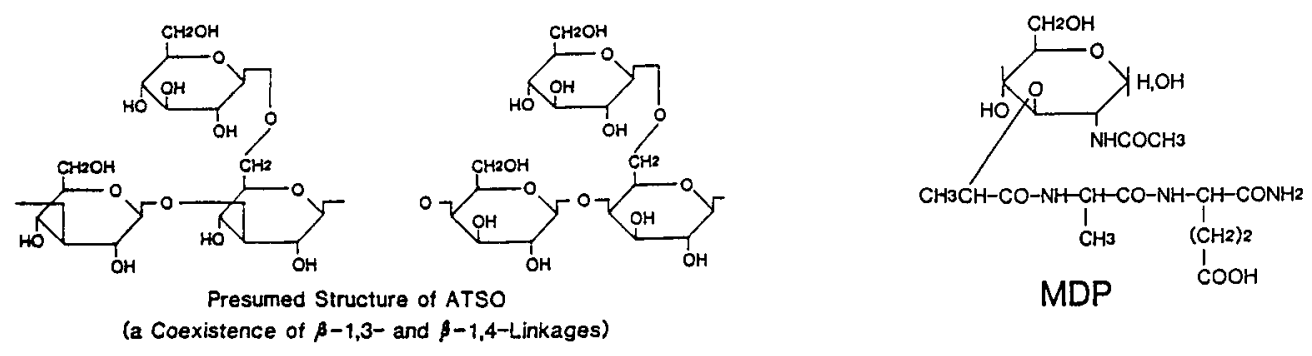

ATSO
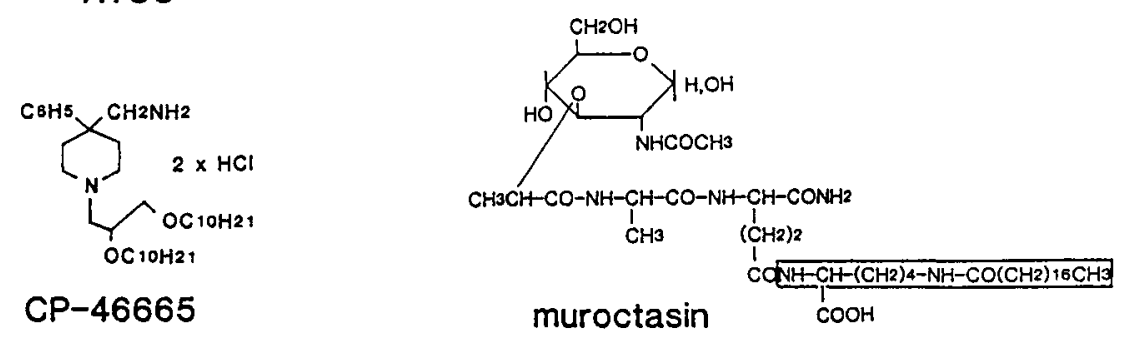

Fig. 1 Chemical Structures of Examind Immunostimulants 
Experiment 1: Groups of 10 female Jcl:AF-nu mice aging 4 weeks were inoculated with $3 \times$ $10^{7} \mathrm{LB}$ into both hind fps. Two groups were fed with $0.005 \%$-DDS chow or $0.005 \%$-DDS plus $0.02 \%$-ATSO chow during the 9 th-21st weeks after inoculation. The latter group was further given ATSO through $0.02 \%$-ATSO chow during the 22 th-32nd weeks. The other two groups were fed with $0.005 \%$-DDS chow during the same period, but further dose with CP-46665 or MDP during the 9 th-32nd weeks. The result is shown in Figure 2. The growth of LB in untreated female $\mathrm{Jcl}: \mathrm{AF}-n u$ mice was comparable to that in athymic BALB/c female mice $\left(^{1}\right)$.

However, when it was compared with a result found in the latter strain of nude mice $\left.{ }^{1}\right)$, the growth inhibitory effect of DDS alone was more clearly exhibited in this strain of hybrid nude mice than that in athymic BALB/c mice. No synergic effect was found by the combination of DDS and ATSO. On the other hand, the combined doses of DDS and CP-46665 or MDP completely inhibited the growth of LB until 49 weeks after inoculation. In these 2 groups, a number of AFB were found to be beaded and short rods.

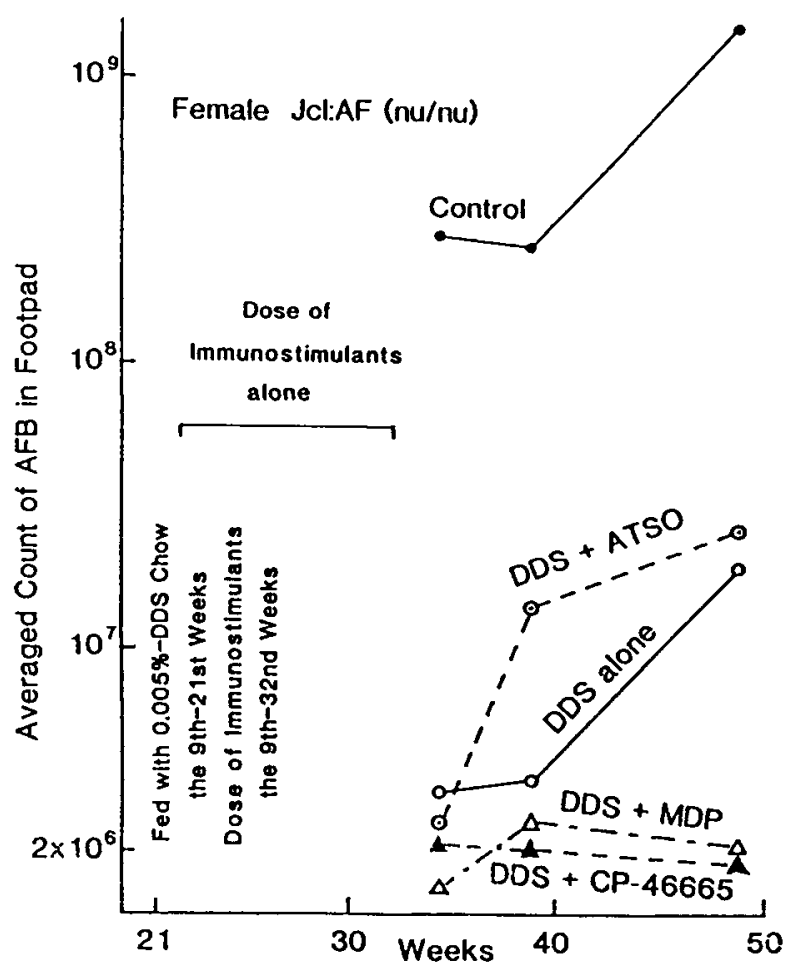

Fig.2 Inhibitory Effects by Combined Doses of DDS and several Immunostimulants on the Growth of Leprosy Bacilli Inoculated into Footpads of Hybrid Nude Mice, Jcl:AF- $n u$ (Female)

Inoculation: $3 \times 10^{7}$ leprosy bacilli (Thai-53, the 6 th passage) into each of both hind footpads Periods of doses: DDS, during the 9th-21st weeks after inoculation; the others, during the 9th-32nd weeks Dosages: ATSO, given through 0.02\%-ATSO chow; MDP, $100 \mu \mathrm{g} /$ mouse or CP-46665, $12 \mu \mathrm{g} /$ mouse, intraperitoneally once per week 
The result in the volumetry of fp swelling showed no significant difference among treated groups. The difference was found only between treated groups and the control. The volumetry of all the fps was thought to be useful for selecting those animals whose swelling of fps was medium throughout the group.

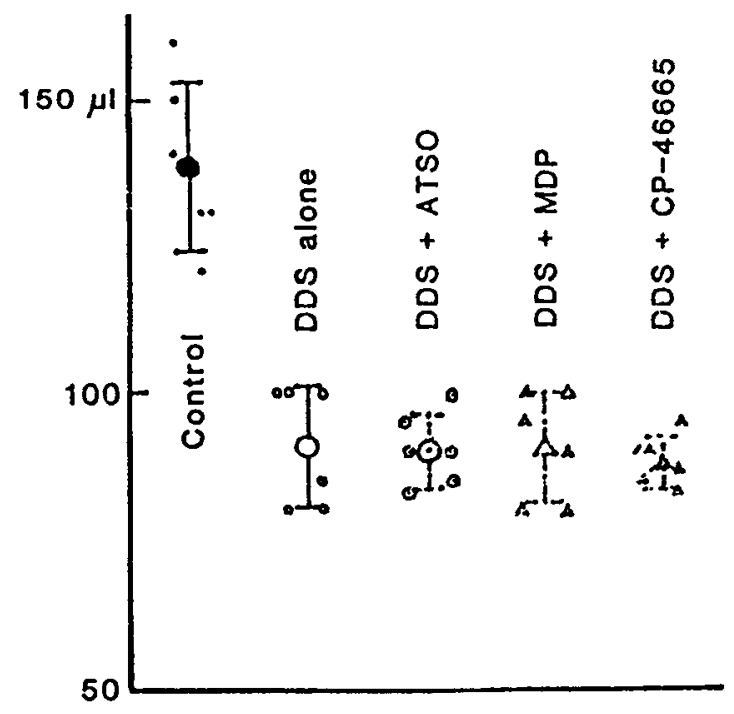

Fig.3 Result in the Volumetry of Footpads in Experment 1 Examined Just Before the Last Sacrifice of Animals

The small marks on the right side of deviation symbols are the volumes of right hind footpads and those on the left side are the volumes of left hind footpads.

Experiment 2: Groups of 9 female Jcl:AF-nu mice aging 5 weeks were inoculated with $6 \times$ $10^{6} \mathrm{LB}$ (the 7th passage) into both hind fps. One group was intraperitoneally dosed with muroctasin once weekly covering the 9th-32nd weeks. Another group was further given DDS during the 9th-21st weeks through $0.001 \%$-DDS chow. A group given DDS alone was not examined due to a clear result in experiment 1. The counting of AFB and the volumetry of fp swelling were started from the 217th day after inoculation. The results are shown in Figures 4 and 5 .

Unexpectedly, muroctasin itself was found to decrease the count of detected AFB and the fp swelling. The combined dose of muroctasin with the chow containing low concentration of DDS $(0.001 \%)$ further decreased the count of AFB, but could not achieve the complete inhibition. If each nude mouse weighing $20 \mathrm{~g}$ takes daily $3 \mathrm{~g}$ of chow, the averaged daily dose of DDS is calculated to be $1.5 \mathrm{mg} / \mathrm{kg}$. In contrast to the complete inhibiton after adminstration of MDP and $0.005 \%$-DDS chow, the inhibitory effect at this dose of DDS was supposed to be insufficient even though combined with muroctasin. 


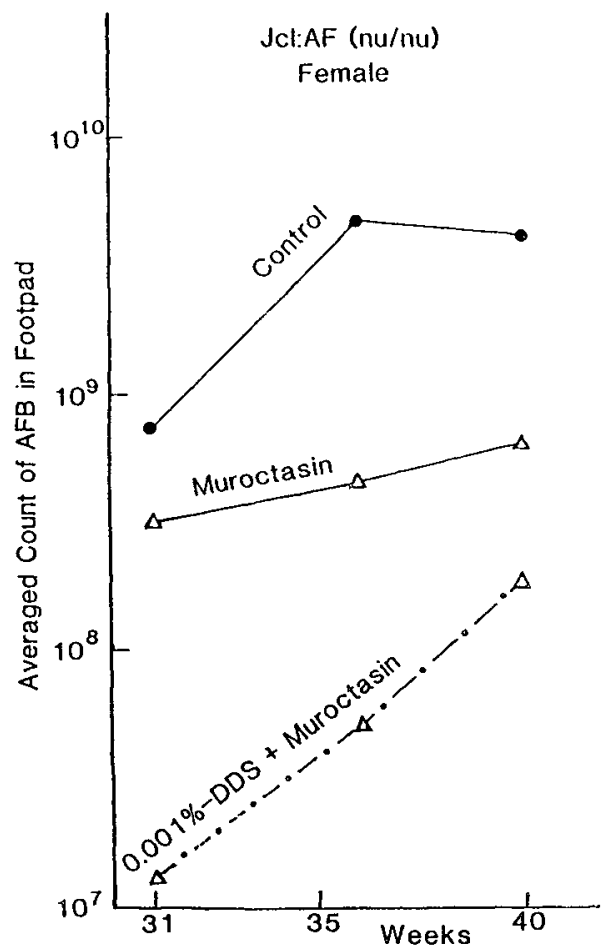

Fig.4 Inhibitory Effects by Muroctasin Alone or Combined Dose of DDS and Muroctasion on the Growth of Leprosy Bacilli Inoculated into Footpads of Female Jcl:AF-nu Mice

Inoculation: $6 \times 10^{6} \mathrm{LB}$ (the 7th passage) into each of both hind footpads Periods of Doses: DDS, during the 9th-21st weeks; muroctasin, during the 9th-32nd weeks Dosages: DDS, given through $0.001 \%$-DDS chow; muroctasin, $75 \mu \mathrm{g} /$ mouse, intraperitoneally once per week

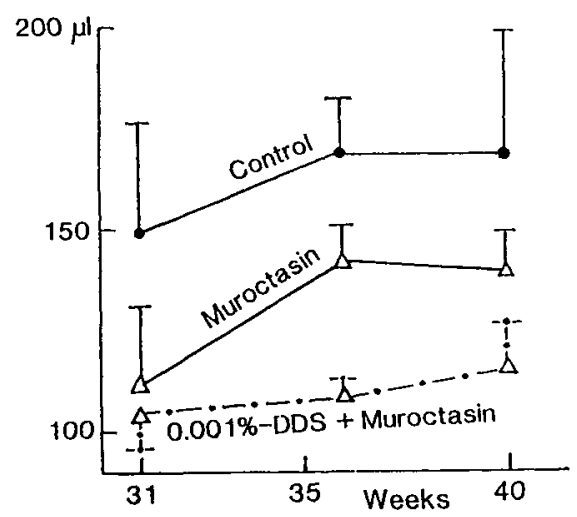

Fig.5 Result in the Volumetry of Footpads in Experiment 2,

Examined Just After Sacrificed Animals 


\section{Discussions}

It is a well-known fact that both the adaptability of a tumor cell line to a strain of nude mice and the inhibitory effect of an antitumor agent on the tumor cells proliferating in the nude mice are varied with the strain of nude mice. This fact suggests at the same time that an immunologcal level of nude mice varies with strains.

Macdonald, et al. $\left({ }^{2}\right)$ and Lawetzky, et al. $\left(^{3}\right)$ reported the presence of $\mathrm{T}$ cell antigen receptor expression in nude mice if the nude mice were aged more than $4-5$ months.

Gillis, et al. $\left({ }^{4}\right)$ reported that the nude mouse spleen cells could become responding to alloantigen sensitization in mixed lymphocyte cultures by the presence of a $\mathrm{T}$ cell growth factor . Wagner, et al. $\left(^{5}\right)$ also reported that the injection of allogenic stimulator cells and IL-2 could differentiate in vivo the nude mouse lymphocytes into alloreactive cytotoxic $T$ lymphocytes. Both reports indicated the persence of $\mathrm{T}$ cell immunity in nude mice if they had received an IS pre-treatment.

On the other hand, Kawashima, et al. had reported that a cell population of prethymic $\mathrm{T}$ cell precursor was mainly found in the spleen of athymic BALB/c mice whereas it was mainly found in the peripheral lymph nodes in athymic Swiss mice $\left({ }^{6}\right)$. They also suggested that the prethymic cells in both strains of nude mice were derived from the degenerating thymus glands in the nude mouse fetuses. The reason why we dosed the immunostimulants covering 24 weeks or till the end of the 8th month after birth of nude mice was based on these preceding findings in which the possible differentiation of cell subpopulations in aged nude mice was suggested to be responsible for the competence of their $\mathrm{T}$ cell immunity.

Practically, Pimm, et al. $\left(^{7}\right)$ had found the regression of 2 immunogenic tumor cell lines, a rat sarcoma Mc7 and a rat hepatoma D 23 in their transmitted nude mice after vaccinated them with $B C G$.

In experiment 1 , an antitumor $\beta$-1,3-glucan, ATSO with a mild immunopotentiative activity was the substance purified from a crude fraction (corresponding to krestin) of Basidiomycete (Coriolus versicolor) by eliminating its protein component $\left({ }^{8}\right)$. The growth of LB was completely inhibited by a combined dose of DDS and MDP or CP-46665, but could not be inhibited by a combination of DDS and ATSO.

The arthrogenous lipoidal amines have been oncologically used as immunostimulants. CP. 20961 (avridine), a strictly lipophilic lipoidal amine, was once examined by us. However, the emulsion dissolving avridine seemed to be injurious and the nude mice intraperitoneally injected the emulsion (an ethanolic solution of avridine-tween 80-soy bean oil (3:1:45.9)) very gradually died. Since avridine was presumed to be unsuitable for such a long term treatment, CP-46665, a freely water soluble lipoidal amine, was examined, whose arthritogenetic potential was found to be comparable to that of avridine $\left(^{9}\right)$.

Saiki, et al. $\left({ }^{10}\right)$ and Parant, et al. $\left({ }^{11}\right)$ examined some lipophilic derivatives of MDP such as benzoquinonyl MDP and 1-O-MDP-glycerol-3-mycolate, respectively. The development of MDP derivatives having lipophilic radicals at its muramyl ring such as 6-O-mycoloyl-MDP $\left({ }^{12}\right)$ or those substituted some lipophilic acyl- $\mathrm{NH}$ radicals for $\mathrm{NH}_{2}$ in its peptide side residue had been endeavored. Amongst these examinations, Parant, et al. alone found a nonspecific IS activity in a desmuramyl compound, 1-O-(L-alanyl-D-isoglutamine-L-alanyl) glycerol-3-mycolate. Though an 
emulsion of MDP and trehalose-6,6'-dimycolate regressed the proliferation of some tumor cell lines and eliminated lymph node metastasis $\left({ }^{13}\right), \mathrm{MDP}$ itself and its derivatives have played a main part in these experimental IS and finally reached to muroctasin $\left({ }^{14}\right)$.

It was reported that MDP was analgesic $\left({ }^{15}\right)$ in spite of its inflammatory actions $\left({ }^{16}\right)$. In addition, muroctasin was found to have an inhibitory effect on edema formation $\left({ }^{14}\right)$ in contrast to the induction of edema by MDP $\left({ }^{17}\right)$. These pharmacodynamic characteristics of muroctasin are presumed to be desirable for treatment of leprosy. Its IS effect superior to MDP was reported in details $\left.{ }^{18}\right)$.

The complete growth inhibition of LB after adminstration of $0.005 \%$-DDS chow and MDP in addition to the partial growth inhibition by muroctasin alone indicated the enhancement of antibacterial effect due to an IS effect by these 2 immunostimulants.

The results in experiments 1 and 2 may suggest the usefulness of this strain of hybrid nude mice to be a favorable animal model for examining the inhibitory effects of CT-IS combinations on the growth of LB.

\section{Summary}

The inhibitory effects by the combined doses of bacteriostatic DDS and several immunostimulants on the growth of leprosy bacilli (LB) inoculated into the footpads of nude mice were examined, using a strain of hybrid nude mice named Jcl:AF-nu, which is resistible to infections more than strain BALB/c-nu.

The results found were:

1. LB could proliferate up to $10^{9}$ level in the footpads of this strain of hybrid nude mice.

2. The combined dose of muramyl dipeptide (MDP) or a water-soluble lipoidal amine, CP46665 and DDS mixed with chow in the content ratio of $0.005 \%$ completely inhibited the growth of LB. Whereas, the growth inhibition by DDS alone was only partial.

3. A derivative of MDP, muroctasin could partially inhibit the growth of LB whithout combined dose of DDS.

4. The combined dose of an antitumor $\beta$-1,3-glucan named ATSO could not enhance the partial growth inhibition due to the dose of DDS through $0.005 \%$-DDS chow.

Based on these results, the possibility of Jcl:AF- $n u$ mice as a favorable animal model for examining the synergic inhibitory effect on the growth of LB due to the combined dose of an antileprous chemotherapeutic and an immunostimulant was discussed.

\section{Acknowledgement}

Authors are grateful to Dr. Sonoko Habu, Assistant professor of Cell Biology, School of Medicine, Tokai University for her pertinent suggestions about the $\mathrm{T}$ cell immunity of nude mice.

\section{References}

1) Tsutsumi,S. and Gidoh, M.: On search for new antileprous compounds and their enhancement with immunostimulants in experimental leprosy. Int. J. Leprosy, 56, 676 (1988) . (abstract)

2) Macdonald, H.R., Lees, R., Bron, C., Sordat, B. and Miescher, G.: T cell antigen receptor expression in athymic $(\mathrm{nu} / \mathrm{nu})$ mice. Evidence for an oligoclonal $\beta$ chain repertoire. J. Exp. Med., 166, 195 209 (1987) . 
3 ) Lawetzky, A . and Hüng, T .: Analysis of CD3 and antigen receptor expression on T cell subpopulations of aged athymic mice. Europ. J. Immunol. , 18, 409-416(1988).

4) Gillis, S.,Union, N.A.,Baker,P.E. and Smith,K.A.: The in vitro generation and sustained culture of nude mouse cytolytic T-lymphocytes. J. Exp. Med., 149, 1460-1476(1979) .

5) Wagner, H., Hardt,C., Heeg,K., Röllinghoff, M. and Pfizenmaier, K.: T cell-derived helper factor allows in vivo induction of cytotoxic $\mathrm{T}$ cells in nu/nu mice. Nature,284, 278-280 (1980).

6) Kawashima,K., Takeyama, H. ,Kobayashi,M. and Yamada,K.: Thymocyte-like cells in nude mouse spleen and lymph nodes. Saishin Igaku,32, 1823-1825(1976)

7) Pimm, M.V. and Baldwin, R.W.: BCG immunotherapy of rat tumours in athymic nude mice. Nature, 254, 77-78(1975).

8) Ito, H., Naruse,S. and Fujii, K.: Studies on antitumor activities of Basidiomycetes. Folia pharmacol. japon., 68, 429-441(1972).

9) Jensen,K.E., Niblack,J.F., Wolff III,J.S.,Kraska,A.R., Otterness, I.G.,Hoffman,W, W. and Hemsworth,G.R.: Exploring the immunotherapeutic potential of two lipoidal amines. pp 55-63, Vol. ,3, In Human Cancer Immunology, Elsever, Amsterdam (1982).

10) Saiki,I., Tanio, Y., Yamawaki, M., Uemiya, M., Kobayashi, M., Fukuda, T., Yukimasa, H., Yamamura, Y. and Azuma, I.: Adjuvant activities of quinonyl-N-acetyl muramyl dipeptides in mice and guinea pigs. Infect. Immun., 31, 114-121(1981).

11) Parant,M.A., Audibert,F.M., Chedid L.A., Level,M.R., Lefrancier,P.L., Choay,J.P. and Lederer, E.: Immunostimulant activities of a lipophilic muramyl dipeptide derivative and of desmuramyl peptidolipid analogues. Infect. Immun.,27, 826-831(1980).

12) Kusunose,S., Odaka, T.,Shiba, T. and Yamamura,Y.: Adjuvant activity of synthetic 6-0"mycoloyl"-N-acetylmuramyl-L-alanyl-D-isoglutamine and related compounds. Infect, Immun., 20. 600-607 (1978).

13) Yarkoni, E. , Lederer, E. and Rapp, H.: Immunotherapy of experimental cancer with a mixture of synthetic muramyl dipeptide and trehalose dimycolate. Infect. Immun. ,32, 273-276(1981) .

14) Ichihara, N., Kanazawa,R., Sasaki,S., Ono,K., Otani, T., Yamaguchi, F. and Une, T.: Phase I study and clinical pharmacological study of muroctasin. Arzneimittelforsch., 38(II), 1043-1069(1988) .

15) Ogawa, $\mathrm{T}$. and Kotani, S.: Analgesic effects of $\mathrm{N}$-acetylmuramyl-L-alanyl-D-isoglutamine in decreasing the acetic acid-induced abdominal-writhing response. Infect.Immun., 55, 494-496(1987).

16) Kotani,S. and Takada,H.: Immunopharmacological activities of bacterial cell walls and related synthetic compounds (muramyl peptides). Yakugaku Zasshi, 103,1-27 (1983).

17) Kojima, H., Hirohashi, M., Kasai, Y., Takasuna, K., Fukumoto,C. and Akashi, A.: General pharmacological properties of muroctasin. Arzneimittelforsch., 38(II), 1002-1009 (1988).

18) Matsumoto, K., Osada, Y., Une, T., Otani, T., Ogawa, H. and Azuma, I.: Anti-infectious activity of the synthetic muramyl dipeptide analogue MDP-Lys(L18).pp79-97, In Azuma,I. and Jollés, G. (eds), Immunosimulants now and tomorrow, Japan Scientific Societies Press, Tokyo and SpringerVerlag (1987). 


\section{交雑ヌードマウス Jcl:AF-nu 足蹠に移植したらい菌の 増殖に対するDDS と二,三の免疫促進物質 の併用投与による阻止効果}

儀 同 政 一.堤 貞 衛

(国立多摩研究所)

キーワード：交雑ヌードマウス, 免疫促進, リポイダルアミン, ムラミルジペプチド, ムロクタシン

$\mathrm{BALB} / \mathrm{c}$ ヌードマウスよりも感染抵抗性の強い 交雑ヌードマウス Jcl:AF-nu を用いて，足蹠接種ら い菌增殖に対する静菌作用しか持たないDDS と二, 三の免疫促進物質の併用投与による阻止効果を調べ たところ, 次の結果を得た。

1, らい菌は当交雑ヌードマウス足蹠で, $10^{9}$ レベ ルまで増殖した。

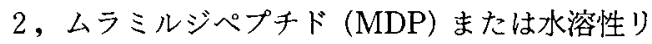
ポイダルアミン CP-46665を0.005\% DDS 混合飼料 で飼育の当交雑ヌードマウスに併用投与するとらい 菌増殖を完全に阻止し，一方 DDS のみでは不完全 な阻止しか示さなかった。
3，MDP の誘導体であるムクロタシンは, DDS を併用投与しなくても不完全阻止ながららい菌増殖 を抑制した。

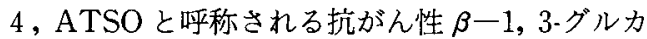
ンは, $0.005 \%$ DDS 混合飼料で飼育のヌードマウス に併用投与しても DDS の阻止効果を増強しなかっ た。

以上の結果に基づき，Jcl:AF- $n u$ マウスは抗らい 化学療法薬と免疫促進物質の併用投与による相乘的 ならい菌阻止効果を調べるのに好便な動物モデルに なりそうな可能性につき討議した。 